\title{
Accounting History Research: Scope, Topics and Agenda
}

\author{
Salvador Carmona
}

IE University, IE Business School, Madrid, Spain

Email: salvador.carmona@ie.edu

\section{GALVANIZING RESEARCH: INSTITUTIONS}

Since the 1970s, accounting history has built a considerable research infrastructure (e.g. congresses, journals, and associations) that supports networking, as well as the dissemination of studies in this area. This editorial reviews research trends in accounting history and suggests four areas: (i) new settings and observation periods; (ii) accounting in native nations; (iii) gender; and (iv) accounting and the State hold promise to advance accounting knowledge.

In 1970, Ernest Stevelinck organized in Brussels the first World Congress of Accounting Historians, which signaled the awakening of accounting history research as an academic discipline. World congresses instilled in accounting historians the practice of receiving highquality feedback on their studies before submitting their papers to a journal or their books to a publisher. In 1973, Gary J. Previts lead the foundation of The Academy of Accounting Historians. For accounting historians, the Academy became a reference for networking, as well as for research dissemination. Thus, the Academy launched the first specialized journal in the area, The Accounting Historians Journal (AHJ), in 1974.

Drawing on these institutional bases (e.g. congress, academic organization, academic journal), accounting history research was no longer practiced by a few, highprofile scholars, such as Basil Yamey, and his contributions to the role played by accounting in the rise of capitalism (Yamey, 1949, 1964), or David Solomons, and his influential work on advanced costing practices in the late $19^{\text {th }}$ century (Solomons, 1952). Instead, this academic infrastructure propelled the visibility of accounting history research and raised interest among a growing number of scholars, who were established in a large number of developed countries.

Research generally focused on examining the origins of accounting and double-entry bookkeeping. Stevelinck and co-authors addressed accounting in ancient times (Stevelinck \& Most, 1985) and biographical and artistic aspects of Pacioli's figure (Stevelinck, 1986, 1994). Furthermore, studies examining the origins of doubleentry bookkeeping focused on wider contexts that witnessed the publication of Pacioli's Summa, as well as its technical underpinnings (Williams, 1978; Antinori, 1994; Hernández Esteve, 1994). This stream of research also offered important contributions on the early dissemination of double-entry bookkeeping in various industries - e.g. the Spanish public sector (Hernández Esteve, 1986); sale of precious metals (Donoso Anes, 1994). Additionally, accounting historians conducted significant studies on biographical aspects - e.g. Federigo Melis (see Garner, 1976); British contributions (see Parker \& Yamey, 1994) -, as well as on the role played by accounting educators (Zeff, 1999, 2000). On the other hand, studies on the origins and fundamentals of accounting did not neglect cost accounting practices; Wells (1977) examined the development of cost accounting and Hallbauer (1978) analyzed the relationship of cost accounting with other disciplines (e.g. scientific management). Finally, historical research also addressed how leading industries contributed to developing innovative accounting practices - e.g. railroads (Boockholdt, 1978; Previts \& Samson, 2000).

Overall, accounting history research focused on topics such as the origins of double-entry bookkeeping, accounting's role in the rise of capitalism, biography, the emergence and evolution of cost accounting practices, and how some industries contributed to the development of accounting practices and theory. To do this, historical research drew on primary or secondary sources to focus on the description of historical events and few attempts were made to engage historical evidence in an informing, theoretical framework. Finally, the international profile of accounting history research was worth noting, especially considering the communication and logistics structure of this period; since its foundation, the AHJ published articles addressing accounting practices in a variety of international settings (e.g. Greece, India, Italy, Japan). 


\section{GAINING MOMENTUM}

The rigor and importance of accounting history research received significant endorsement from wellestablished scholars. In a context where the USA was losing its industrial supremacy to Japan, management accounting witnessed a thorough debate on the relevance of cost data for performance evaluation and managerial decision-making (Kaplan, 1983). It was argued that financial accounting principles overruled cost accounting practices in firms, which leaned towards reporting goals instead of providing management with relevant data for decision-making and control purposes. In the context of this debate, Johnson and Kaplan (1986) adopted a historical perspective in support of the 'relevance' of cost data; the authors suggest that the implementation of early cost accounting systems that took place during the British Industrial Revolution was motivated by efficiency purposes; increasing competition slashed the firms' profit margins and they had to implement costing systems for efficiency improvement purposes. From a different perspective, Hopwood (1987) examined accounting change processes and the need to learn more about the preconditions of such a change. The author suggests that research in accounting change should be embedded in its wider social contexts and that contributions to the theorization of accounting require engagement in theoretical frameworks (e.g. Foucault, 1972, 1977; Giddens, 1984). Hopwood (1987) also adopted a historical perspective and drew on Foucault's framework of power/ knowledge to stress accounting's role as an instrument of distance control, an approach that had been enforced in prisons and benefitted from architectural design (e.g. Bentham's panopticon).

Kaplan and Hopwood's calls for a historical approach towards the relevance of cost data and the examination of accounting change processes exerted a significant influence on the research agenda. Furthermore, such calls enhanced the visibility and impact of ongoing historical research. Fleischman and Parker (1991) examined cost accounting data of firms operating during the British Industrial Revolution and found four major areas of activity: (i) cost control techniques; (ii) accounting for overhead; (iii) costing for routine and special decisionmaking; and (iv) standard costing. On the other hand, and adopting a sociological approach to examine historical events, Hoskin and Macve $(1986,1988)$ analyzed the published histories of the U.S. armories and railroads to address the genesis of the new managerialism. They traced back the implementation of a rigorous human accountability system in these industries to influence graduates from the U.S. Military Academy, an elite educational institution, which was well-advanced with disciplinary power elements such as the panopticon.

So, there were two approaches to conduct accounting history research, which focused either on the technical and economic aspects of accounting systems or on the sociological ones. Such approaches were examined by Ezzamel, Hoskin and Macve (1990), in their review of Johnson and Kaplan's Relevance Lost. Along these lines, Miller, Hopper and Laughlin (1991) commented on accounting history research conducted during the 1980s and identified two strands, which they labeled as traditional and new accounting history, respectively. Napier (2009), in his comprehensive review of accounting history research, supported Miller and co-authors categorization of traditional and new accounting history, but proposed a less presumptuous terminology: historical accounting and socio-historical accounting. The former deals with the technicalities of the accounting craft, while the latter tries to engage historical evidence in sociological and managerial frameworks. Regarding the socio-historical categorization, there were two main streams of research: Marxist (Bryer, 2005) and Foucauldian (Carmona, Ezzamel, \& Gutiérrez, 1997, 2002). Overall, the distinction between the traditional/ new accounting history perspective and the new/sociohistorical one shows to be intellectually valid, but not necessarily contradictory. As shown by the historical evidence provided by Carmona, Ezzamel and Gutiérrez (2004), an integration of both approaches is feasible and this might enhance the strength of accounting history research.

Accounting history research kept growing over the last decades. From an institutional standpoint, two international specialized journals were created: Accounting, Business and Financial History, founded by Dick Edwards and Trevor Boyns, which changed its name to Accounting History Review, then it was edited by Steve Walker and Cheryl McWatters; and Accounting History, which was founded and edited by Garry Carnegie with co-editors. Furthermore, some specialized journals were published in some jurisdictions (e.g. in Spain: De Computis, founded by Esteban Hernández Esteve and currently edited by Fernando Gutiérrez Hidalgo). Also, an increasing number of specialized workshops and conferences on accounting history signaled that this high-profile academic infrastructure has led accounting history research to gain momentum (see Napier, 2006, 2009). 


\section{CHALLENGES AND OPPORTUNITIES: A RESEARCH AGENDA}

The accounting history evolution provides us with some opportunities for further research in this area. In my view, investigations addressing (i) settings and observation periods that are widely neglected by extant research, (ii) accounting in native nations, (iii) gender, and (iv) accounting and the State hold promise to add to the categorizations of accounting history research noted above (e.g. accounting history/socio-historical accounting).

\subsection{Time-space}

Accounting history research is still dominated by a rather thin time-space intersection, i.e. Anglophone countries and the observation period 1850-1945 (Carmona, 2006; Walker, 2006, 2009). Paraphrasing Scott (1995), it might be difficult, if not impossible, to improve knowledge in our discipline if all our cases were taken from the same, or very similar, contexts. Therefore, accounting history research drawing on jurisdictions that have been widely neglected by papers published in generalist and specialist journals hold promise to contribute to the discipline. Such investigations provide new accounting evidence and theorization. Although accounting history is improving its international profile vis-à-vis the situation described by Carnegie and Potter (2000) and Carmona (2004), further research addressing other settings (e.g. Latin America, Africa) and various time periods (e.g. Present Time History, Middle Ages, Renaissance) might enhance the discipline's profile. For instance, studies drawing on this new time-space may address accounting's role in slavery and smuggling (e.g. $18^{\text {th }}$ century Latin-America - see Carmona, Donoso, \& Reckers, 2013; Pinto \& West, 2017).

\subsection{Native nations}

We still have much to learn about accounting and organizational practices of indigenous people (for a comprehensive work, see Greer \& Neu, 2009). Such stream of research claims that history traditionally focused on the so-called winners' records and stories, hence not much is known about those people that were colonized, defeated, or even genocided by advanced nations. This stream emerged after the seminal work by Brown (1970) on Native Americans in the American West during the late $19^{\text {th }}$ century. As aptly noted by Sy and Tinker (2005), examining accounting and organizational practices among non-Western tribes and people may bring difficulties with supporting evidence, especially if approached from a traditional, Western perspective (e.g. written records). However, there is a need to be optimistic about this: papers in generalist and specialist journals show that editors are flexible regarding research supported by nonconventional accounting sources (e.g. oral history), and this study type may enhance the discipline's growth. For instance, Annisette (2006) focused on pre-colonial Africa to examine the ancient Yoruba practice and how such a practice may enhance knowledge about the 'truly unfamiliar.'

\subsection{Gender}

There is a sparse, but growing stream of research examining the relationship between accounting and gender. As doing gender is indeed a cultural concept, there is an opportunity for accounting historians to make a significant contribution to this area. To do this, the relationship between accounting and gendered space (e.g. household, workplace) provides excellent research opportunities. Furthermore, extant research has enhanced knowledge in this area: Walker (1998) examined accounting's role in everyday life in British households during the $19^{\text {th }}$ century and found that accounting techniques were thoroughly implemented in the middleclass family. It is worth highlighting that accounting was used as an instrument of men's domination, constraining women's consumption and to limiting women's lives to domestic roles. Carmona, Ezzamel and Mogotocoro (forthcoming) examined the relationship between gender, management styles, and forms of capital in Cartagena de Indias (present-day Colombia) during the $18^{\text {th }}$ century and found that stereotypic management styles were selectively deployed, which included a masculine management style that supported financial decision-making and business transactions, whilst a feminine management style helped enhancing social capital. As for the relationship between accounting and gendered workplace, Carmona and Ezzamel (2016) suggested three main areas of research: (i) how human gaze produces gender divisions at work; (ii) how accounting works as a gaze and produces gender divisions in the workplace, while noting the scope for resistance; and (iii) how gendered accounting technologies reaffirm existing gender divisions.

\subsection{Accounting and the State}

The State's role in social and economic activities has varied across countries and regions and accounting has 
not played a neutral role in the States' structure and organization (Miller, 1990). In some jurisdictions (e.g. $16^{\text {th }}$ century Venice - see Zan, 2004), the State exerted stiff control over the economy and enforced sophisticated labor and control processes through managerial and control resources. In other constituencies (e.g. $18^{\text {th }}$ century LatinAmerica), the State became a workforce supplier through slave trading, which constituted a profitable business, but also a pretext for smuggling (Carmona, Donoso, \& Walker, 2010). In the $18^{\text {th }}$ century, the supply of slaves to Spanish colonies in Latin-America was outsourced to Britain and accounting became key in the international relations between these States (e.g. wars).

\section{CONCLUDING REMARKS}

Accounting history research provides excellent opportunities to advance empirical knowledge about the functioning of accounting systems, as well as to enhance accounting theorization. Since the 1970s, accounting history has built a considerable research infrastructure (e.g. congresses, journals, and associations) that supports both networking and research dissemination in the area. This editorial suggests that historical research focusing on four areas hold promise to advance accounting knowledge.
However, these areas should not be considered in a restrictive way, as many others will certainly contribute to accounting history research. Importantly, young, emerging, and senior scholars conducting initial studies in this area may wish to adopt an ambitious standpoint towards their investigations; they can rate high in both historical evidence and theoretical contribution. Such an approach will enhance their possibilities to get papers published in top-tier, premier outlets.

\section{REFERENCES}

Annisette, M. (2006). People and periods untouched by accounting history: an ancient Yoruba practice. Accounting History, 11(4), 399-417:

Antinori, C. (1994). Luca Pacioli e la Summa de arithmetica. Roma: Istituto Poligráfico e Zecca dello Stato.

Boockholdt, J. L. (1978). Influence of nineteenth and early twentieth century railroad accounting on the development of modern accounting theory. The Accounting Historians Journal, 5(1), 9-28.

Brown, D. (1970). Bury my heart at wounded knee: an Indian history of the American West. Holt, Rinehart and Winston: New York.

Bryer, R. A. (2005). A Marxist accounting history of the British Industrial Revolution: a review of evidence and suggestions for research. Accounting, Organizations and Society, 30(1), 25-65.

Carmona, S. (2004): Accounting history research and its diffusion in an international context. Accounting History, 9(3), 7-23.

Carmona, S. (2006). Performance reviews, the impact of accounting research, and the role of publication forms. Advances in Accounting, 22, 241-267.

Carmona, S., Donoso, R., and Reckers, P. M. (2013). Timing in accountability and trust relationships. Journal of Business Ethics, 112(3), 481-495.

Carmona, S., Donoso, R., \& Walker, S. P. (2010). Accounting and international relations: Britain, Spain and the Asiento Treaty. Accounting, Organizations and Society, 35(2), 252-273.

Carmona, S., \& Ezzamel, M. (2016). Accounting and lived experience in the gendered workplace. Accounting, Organizations and Society, 49, 1-8.
Carmona, S., Ezzamel, M., \& Gutiérrez, F. (1997). Control and cost accounting practices in the Spanish Royal Tobacco Factory. Accounting, Organizations and Society, 22(5), 411446.

Carmona, S., Ezzamel, M., \& Gutiérrez, F. (2002). The relationship between accounting and spatial practices in the factory. Accounting, Organizations and Society, 27(3), 239-274.

Carmona, S., Ezzamel, M., \& Gutiérrez, F. (2004). Accounting history research: traditional and new accounting history perspectives. De Computis: Spanish Journal of Accounting History, 1(1), 24-53.

Carnegie, G. D., \& Potter, B. N. (2000). Publishing patterns in specialist accounting history journals in the English language, 1996-1999. The Accounting Historians Journal, 5(2), 177-198.

Donoso Anes, R. (1994). The Casa de la Contratación de Indias and the application of double entry bookkeeping to the sale of precious metals in Spain, 1557-83. Accounting, Business \& Financial History, 4(1), 83-98.

Ezzamel, M., Hoskin, K., \& Macve, R. (1990). Managing it all by numbers: a review of Johnson \& Kaplan's 'Relevance Lost'. Accounting and Business Research, 20(78), 153-166.

Fleischman, R. K., \& Parker, L. D. (1991). British entrepreneurs and pre-industrial revolution evidence of cost management. Accounting Review, 66(2), 361-375.

Foucault, M. (1972). Archaeology of knowledge. Oxon: Routledge. Foucault, M. (1977). Discipline and punish: the birth of the prison. New York: Vintage.

Garner, S. P. (1976). The Melis testimonial. The Accounting Historians Journal, 3(1-4), 13-15. 
Giddens, A. (1984). The constitution of society: Outline of the theory of structuration. Cambridge: Polity.

Greer, S., \& Neu, D. (2009). Indigenous peoples and colonialism. In J. R. Edwards \& S. P. Walker (Ed.), The Routledge companion to accounting history (pp. 470-484). London: Routledge.

Hallbauer, R. C. (1978). Standard costing and scientific management. The Accounting Historians Journal, 5(2), 27-51.

Hernández Esteve, E. (1986). Pedro Luis de Torregrosa, primer contador del libro de Caxa de Felipe II. Introducción de la contabilidad por partida doble en la Real Hacienda de Castilla (1592). Revista de Historia Económica, 3(2), 221-245.

Hernández Esteve, E. (1994). Luca Pacioli, de las cuentas y las escrituras, Título Noveno. Tratado XI de su Summa de Arithmetica, geometria, proportione et proportionalita. Madrid: AECA.

Hopwood, A. G. (1987). The archeology of accounting systems. Accounting, Organizations and Society, 12(3), 207234.

Hoskin, K. W., \& Macve, R. H. (1986). Accounting and the examination: a genealogy of disciplinary power. Accounting, Organizations and Society, 11(2), 105-136.

Hoskin, K. W., \& Macve, R. H. (1988). The genesis of accountability: the West Point connections. Accounting, Organizations and Society, 13(1), 37-73.

Johnson, H. T., \& Kaplan, R. S. (1986). Relevance lost: the rise and fall of management accounting. Cambridge, MA: Harvard Business Press.

Kaplan, R. S. (1983, October). Measuring manufacturing performance: a new challenge for managerial accounting research. Accounting Review, 57, 686-705.

Miller, P. (1990). On the relations between accounting and the State. Accounting, Organizations and Society, 15(4), 315-338.

Miller, P., Hopper, T., \& Laughlin, R. (1991). New accounting history. An introduction. Accounting, Organizations and Society, 16(5/6), 395-403.

Napier, C. J. (2006). Accounts of change: 30 years of historical accounting research. Accounting, Organizations and Society, 31(4), 445-507.

Napier, C. J. (2009). Historiography. In J. R. Edwards \& S. P. Walker (Ed.), The Routledge Companion to Accounting History (pp. 30-49). Oxon: Routledge.

Parker, R. H., \& Yamey, B. S. (1994). Accounting history: some British contributions. Oxford: Oxford University Press.

Pinto, O., \& West, B. (2017). Accounting, slavery and social history: the legacy of an eighteenth-century Portuguese chartered company. Accounting History, 22(2), 141-166.

Previts, G. J., \& Samson, W. D. (2000). Exploring the contents of the Baltimore and Ohio Railroad Annual Reports: 1827 1856. The Accounting Historians Journal, 27(1), 1-42.

Scott, W. R. (1995). Institutions and organizations. Thousand Oaks, CA: Sage.

Solomons, D. (Ed.). (1952). Studies in costing. London: Sweet \& Maxwell.

Stevelinck, E. (1986). The many faces of Luca Pacioli: iconographic research over thirty years. The Accounting Historians Journal, 13(2), 1-18.

Stevelinck, E. (1994). Goodbye to my friend Pacioli. The Accounting Historians Journal, 21(1), 1-15.

Stevelinck, E., \& Most, K. S. (1985). Accounting in ancient times. The Accounting Historians Journal, 12(1), 1-16.

Sy, A., \& Tinker, T . (2005). Archival research and the lost worlds of accounting. Accounting History, 10(1), 47-69.

Walker, S. P. (1998). How to secure your husband's esteem. Accounting and private patriarchy in the British middle class household during the nineteenth century. Accounting, Organizations and Society, 23(5/6), 485-514.

Walker, S. P. (2006). Current trends in accounting history. Irish Accounting Review, 13(2), 107-121.

Walker, S. P. (2009). Structures, territories and tribes. In J. R. Edwards \& S. P. Walker (Ed.), The Routledge companion to accounting history (pp. 11-29). Oxon: Routledge.

Wells, M. C. (1977). Some influences on the development of cost accounting. The Accounting Historians Journal, 4(2), 47-62.

Williams, J. J. (1978). A new perspective on the evolution of double-entry bookkeeping. The Accounting Historians Journal, 5(1), 29-40.

Yamey, B. S. (1949). Scientific bookkeeping and the rise of capitalism. The Economic History Review, 1(2/3), 99-113.

Yamey, B. S. (1964). Accounting and the rise of capitalism: further notes on a theme by Sombart. Journal of Accounting Research, 2(2), 117-136.

Zan, L. (2004). Accounting and management discourse in protoindustrial settings: the Venice Arsenal in the turn of the $16^{\text {th }}$ century. Accounting and Business Research, 34(2), 145-175.

Zeff, S. A. (1999). Henry Rand Hatfield: humanist, scholar, and accounting educator. Stamford, CT: JAI Press.

Zeff, S. A. (2000). John B. Canning: a view of his academic career. Abacus, 36(1), 4-39. 